ISSN 1392-3196 / e-ISSN 2335-8947

Zemdirbyste-Agriculture, vol. 108, No. 3 (2021), p. 233-240

DOI 10.13080/z-a.2021.108.030

\title{
The impact of wheat and faba bean intercrop on the competitive interactions, grain yield, biochemical parameters and mineral content of leaves
}

\author{
Hasnaa SAMMAMA ${ }^{1,2}$, Mimoun El KAOUA ${ }^{2}$, Driss HSISSOU ${ }^{2}$, Salma LATIQUE ${ }^{3}$, \\ Karima SELMAOUI ${ }^{3}$, Mohamed Najib ALFEDDY ${ }^{1}$
}

\author{
${ }^{1}$ The Regional Center for Agronomic Research of Marrakesh, Plant Protection Unit \\ Marrakesh, Morocco \\ E-mail: hasnaa.sammama@edu.uca.ac.ma \\ ${ }^{2}$ Cadi Ayyad University, Faculty of Sciences and Technology \\ Gueliz-Marrakesh 40000, Morocco \\ ${ }^{3}$ Ibn Tofail University, Faculty of Sciences \\ Kenitra, BP.133, 14020 Morocco
}

\begin{abstract}
Various studies highlight the advantages of intercropping, including the improvement of plant growth, stabilization of yield and reduction of economic and environmental risks common in monoculture systems. The research was carried out over two cropping seasons with different $\mathrm{N}$ fertilisation levels to compare winter wheat (Triticum aestivum L.) cultivar 'Wafia' and faba bean (Vicia faba L.) cultivar 'Alfia' cultivated as sole crops or intercropped. The aim of the current study was to evaluate intercrop efficiency using indices such as the land equivalent ratio (LER) and the interspecific (IE) and intraspecific (IA) interaction indices, and to verify whether the wheat and faba bean intercropping improves grain yield, biochemical properties and macronutrient uptake of two cultivars in the systems with low levels of nitrogen $(\mathrm{N})$ inputs.

The research results showed that without $\mathrm{N}$ input the LER $>1$ indicates the most efficient use of environmental resources by intercropping. Without fertilisation, in the $2^{\text {nd }}$ experiment, the IE of soft wheat was equal to 1 indicating that the presence of legume in the intercropping did not affect wheat plant productivity compared to sole crops in half density. However, in the $1^{\text {st }}$ experiment, the presence of the legume was associated with a greater facilitation effect on wheat intercrop (IE > 1) inducing an increase in yield compared to half density. For both experiments, IA of wheat was less than 1 revealing that the wheat yield in half density was higher than that in sole crops in full density. Eventually, the intercrops for both experiments without any $\mathrm{N}$ fertiliser increased the protein, sugar, chlorophyll content and nitrate reductase activity of both intercropped species compared to the untreated and treated sole crops. Likewise, the uptake of macronutrients $\mathrm{P}$ and $\mathrm{K}$ was increased in faba bean intercropped in the $1^{\text {st }}$ and $2^{\text {nd }}$ experiment, respectively, when these elements were less available in the soil. However, Ca content did not show any significant effect. This allows us to conclude that intercropping of soft wheat and faba bean is a relevant way to reduce chemical inputs.
\end{abstract}

Key words: interspecific and intraspecific interaction, intercropping, land equivalent ratio, Triticum aestivum, Vicia faba, nitrogen fertilisation.

\section{Introduction}

To meet the challenge of food security, agricultural production must increase on the existing land; therefore, crop production must be intensified per unit of agriculture land. Therefore, mineral nutrients are the major contributor to enhancing crop production thus promoting economic development. Nowadays, the massive use of nitrogen (N), phosphorus (P) and potassium $(\mathrm{K})$ fertilisers has made it possible to significantly increase world cereal production. However, this rise of production was associated with an increase in the consumption of chemical inputs reflecting a decrease in the efficiency of nutrient use by crops, significant pollution of groundwater and surface water (Zhang et al. 2015 ), and the degradation of soil quality (decrease in organic matter content, alteration of physico-chemical

properties) leading to a decrease in soil fertility and the triggering of erosion processes (Obalum et al., 2017). Currently, an environmental awareness is taking place at the societal and political level raising the question of the innovative management methods and the design of alternative cropping systems. Thus, the objective now is to orient farming systems towards more environmentally friendly practices, while maintaining a sufficient level of economic profitability and ensuring sufficient and quality agricultural production (Lithourgidis et al. 2011). These alternatives include the use of integrated soil fertility management practices, which is part of sustainable organic agriculture through the introduction of intercropping systems. The latter can be defined as the simultaneous cultivation of two or more species on

Please use the following format when citing the article:

Sammama H., El Kaoua M., Hsissou D., Latique S., Selmaoui K., Alfeddy M. N. 2021. The impact of wheat and faba bean intercrop on the competitive interactions, grain yield, biochemical parameters and mineral content of leaves. Zemdirbyste-Agriculture, 108 (3): 233-242. DOI 10.13080/z-a.2021.108.030 
the same area for a significant period of their growth but without necessarily sown and harvested at the same time (Li et al., 2013).

It is supposed that the intercropped species can improve the acquisition of a resource (water, light and nutrients) through two general mechanisms: the differentiation of the acquisition of the resource and the increase of its availability following the modification of the environment by the intercropped species (Shen et al. 2013; Ehrmann, Ritz, 2014; Li et al., 2014). The potential benefits of intercropping compared to monospecific crops would be more interesting in the cases, where the availability of resources is low and would make intercropping efficient low-input systems.

These combinations, particularly cereal-legume intercrops, were established in the cultural traditions of many tropical and subtropical regions. As a result, several studies report the advantage of legume-cereal intercrops on yield stability (Rusinamhodzi et al., 2012; Smith et al., 2013), improving the efficiency of soil resource use compared to monoculture through complementarity, facilitation and competition between intercropped species (Devau et al., 2011; Latati et al., 2013), and the efficiency of interception and use of light energy using different aerial and life cycle architectures of the two crops (ShiliTouzi et al., 2010).

In addition, the intercropping system showed a significant and almost systematic improvement of cereal protein content, a reduction of attacks of cereal diseases and pests such as aphids and pea leaf weevils, which legumes are susceptible to, and also a reduction of weed incidence compared to sole crops (Fernández-Aparicio et al., 2011; Jamshidi et al., 2013). Moreover, such combinations make it possible to mobilize by legumes atmospheric nitrogen $(\mathrm{N})$ inaccessible to cereals, which in turn benefit from a greater share of the $\mathrm{N}$ supplied by the soil, i.e., they also have the advantage over sole legume crops by limiting the risk of nitrate $\left(\mathrm{NO}^{3-}\right)$ leaching to the groundwater, thus providing better soil protection against erosion (Fustec et al., 2010; Gbakatchetche et al., 2010). In fact, the legume-cereal intercropping has made it possible to increase $\mathrm{P}$ levels in the rhizosphere, particularly in Pdeficient soils (Betencourt et al., 2012). This is due to facilitation mechanisms provided by legumes, which are responsible for the high bioavailability of inorganic
$P$ resulting from acidification of the rhizosphere during molecular nitrogen $\left(\mathrm{N}_{2}\right)$ fixation by legumes.

Thus, the deficiency of Moroccan soils in minerals essential to crop growth leads to the need for frequent application of chemical fertilisers, but their regular use has become costly and environmentally disadvantageous resulting in degradation of soil quality, pollution of groundwater by nitrates and non-rational phytosanitary treatments. This led to emphasizing the need to develop cultural practices involving a diversity of crops in order to sustainably maintain crop productivity.

The objectives of the present study were: (1) to evaluate the agronomic performance: yield, land equivalent ratio (LER), interspecific (IE) and intraspecific (IA) interaction indices, of wheat and faba bean intercrop; (2) to examine the effect of wheat and faba bean intercrop on biochemical and macronutrient uptake in low levels of $\mathrm{N}$ fertiliser.

\section{Materials and methods}

Cropping systems and experimental design. The field experiments were carried out over two cropping 2018 ( $^{\text {st }}$ experiment) and 2018-2019 (2 $2^{\text {nd }}$ experiment). The $1^{\text {st }}$ experiment was located in the Saada Station of National Institute of Agronomic Research (INRA), about $7 \mathrm{~km}$ to the south of Marrakesh, Morocco; the $2^{\text {nd }}$ experiment was located in the Experimental Station (31 $\left.37^{\prime} 46.7^{\prime \prime} \mathrm{N} ; 8^{\circ} 09^{\prime} 23.4^{\prime \prime} \mathrm{E}\right)$ of the INRA in Marrakesh, Morocco.

The soils are classified as Endocalcari Endogleyic Cambisol Fluvisol according to WRB (2014). Before the field experiment, the soil chemical properties in 0-30 $\mathrm{cm}$ layer were analysed (Table 1). Soil texture was determined by Robinson's method (Baize, 2018); soil organic carbon (SOC) and soil organic matter (SOM) were determined according to Aubert (1978); total nitrogen $\left(\mathrm{N}_{\text {tot }}\right)$ - by the Kjeldhal method (ISO 11261:1995. Soil quality - Determination of total nitrogen - Modified Kjeldahl method); available phosphorus $\left(\mathrm{P}_{2} \mathrm{O}_{5}\right)$ content was measured by the method of Olsen and Sommers (1982); available $\left(\mathrm{K}_{2} \mathrm{O}\right)$ was determined according to Gueguen and Rombauts (1961).

During the $1^{\text {st }}$ and $2^{\text {nd }}$ experiments, the dry

Table 1. Chemical characteristics of soils during the two growing seasons (2017-2018 and 2018-2019)

\begin{tabular}{|c|c|c|c|c|c|c|c|c|}
\hline Treatment & $\begin{array}{l}\text { Depth } \\
\text { cm }\end{array}$ & Texture & $\mathrm{pH}$ & $\underset{\%}{\mathrm{SOC}}$ & $\underset{\%}{\mathrm{SOM}}$ & $\underset{\mathbf{0}}{\mathrm{N}} \mathrm{N}_{\mathbf{0}}$ & $\frac{\mathrm{P}_{2} \mathrm{O}_{5}}{\mathrm{mg} \mathrm{kg}^{-1}}$ & $\underset{\mathrm{mg}_{2} \mathrm{~kg}^{-1}}{\mathrm{~K} \mathrm{O}}$ \\
\hline $\begin{array}{l}1^{\text {st }} \text { experiment } \\
2^{\text {nd }} \text { experiment }\end{array}$ & $\begin{array}{l}0-30 \\
0-30\end{array}$ & $\begin{array}{l}\text { clay-loam } \\
\text { clay-loam }\end{array}$ & $\begin{array}{l}8.7 \\
8.5\end{array}$ & $\begin{array}{l}0.95 \\
0.77\end{array}$ & $\begin{array}{l}1.64 \\
1.34\end{array}$ & $\begin{array}{l}0.15 \\
0.11\end{array}$ & $\begin{array}{l}20 \\
14\end{array}$ & $\begin{array}{l}220 \\
850\end{array}$ \\
\hline
\end{tabular}

season was from May to October. The annual average rainfall was $232 \mathrm{~mm}$ ( $1^{\text {st }}$ experiment $)$ and $100 \mathrm{~mm}\left(2^{\text {nd }}\right.$ experiment). The average air temperature was $20^{\circ} \mathrm{C}$ and $18.7^{\circ} \mathrm{C}$ in autumn, $11.6^{\circ} \mathrm{C}$ and $15.3^{\circ} \mathrm{C}$ in winter, $19.2^{\circ} \mathrm{C}$ and $22.8^{\circ} \mathrm{C}$ in spring and $26.5^{\circ} \mathrm{C}$ and $27.8^{\circ} \mathrm{C}$ in summer, respectively (Figure 1).

The field experiments $\left(1^{\text {st }}\right.$ and $\left.2^{\text {nd }}\right)$ were carried out with wheat (W) (Triticum aestivum L.) cultivar 'Wafia' and faba bean (F) (Vicia faba L.) cultivar 'Alfia'. They were grown as sole crops (SC) in full density, half density sole crops (SC/2) and as intercrops (IC). Three nitrogen (N) treatments: $\mathrm{N}-0 \mathrm{~kg} \mathrm{ha}^{-1} \mathrm{~N}, \mathrm{~N}-50 \mathrm{~kg} \mathrm{ha}^{-1} \mathrm{~N}$ and $\mathrm{N}-100$ $\mathrm{kg} \mathrm{ha}^{-1} \mathrm{~N}$, were evaluated on IC, wheat SC and SC $/ 2$, while faba bean $\mathrm{SC}$ and $\mathrm{SC} / 2$ were grown without $\mathrm{N}$ application. It was effectively hypothesized that $\mathrm{N}$ is not a limiting resource for legumes because of their ability to increase the symbiotic $\mathrm{N}$ fixation from the air to meet their needs; SC and SC/2 were considered as controls. No herbicides or fungicides were applied; the weeding was done manually. The soil plots undergoing the two experiments have never been before cultivated or treated by chemical fertilisers or organic manures. The experimental design was a randomized complete block with three replicates.

Within each block, the treatments $\mathrm{N}_{0} \mathrm{~F}-\mathrm{SC}, \mathrm{N} F$ $\mathrm{SC} / 2, \mathrm{~N}$ W-SC, N W-SC/2, N IC, N.W-SC, N,W-SC $/ 2$ $\mathrm{N}_{1} \mathrm{IC}, \mathrm{N}_{2}^{0} \mathrm{~W}-\mathrm{SC}, \mathrm{N}_{2} \mathrm{~W}-\mathrm{SC} / 2$ and $\mathrm{N}_{2} \mathrm{IC}$ were subdivided randomly and separated by plot buffers: (1) N.F-SC, N.F-SC, N.F-SC: faba bean sole crops in full density at 0,50 and $100 \mathrm{~kg} \mathrm{ha}^{-1} \mathrm{~N}$, respectively; (2) $\mathrm{N}_{0} \mathrm{~F}-\mathrm{SC} / 2, \mathrm{~N}_{1} \mathrm{~F}$ $\mathrm{SC} / 2, \mathrm{~N}_{2} \mathrm{~F}-\mathrm{SC} / 2$ : faba bean sole crops half density at 0 ,

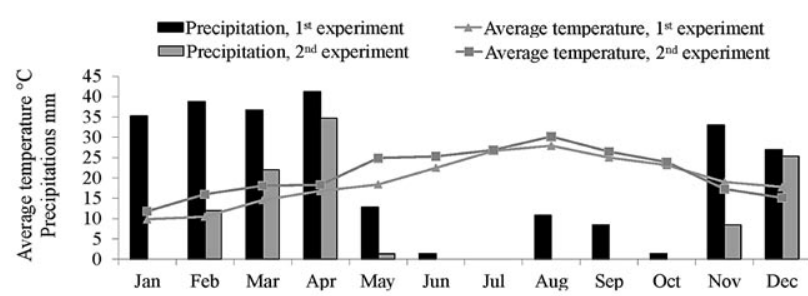

Figure 1. Precipitation and average air temperature during 2017-2018 and 2018-2019 seasons (data of the Marrakesh Meteorological Station)

SC, $\mathrm{N}_{2} \mathrm{~W}-\mathrm{SC}$ : wheat sole crops in full density at 0,50 and $100 \mathrm{~kg} \mathrm{ha}^{2} \mathrm{~N}$, respectively; (4) $\mathrm{N}_{0} \mathrm{~W}-\mathrm{SC} / 2, \mathrm{~N}_{1} \mathrm{~W}-\mathrm{SC} / 2$, $\mathrm{N}, \mathrm{W}-\mathrm{SC} / 2$ : wheat sole crops half density at 0,50 and 100 $\mathrm{kg} \mathrm{ha}^{2} \mathrm{~h}^{-1}$, respectively; and (5) $\mathrm{N}_{-}$IC, $\mathrm{N}_{1}$ IC, $\mathrm{N}_{2}$ IC: faba bean and wheat intercrops at 0,50 and $100 \mathrm{~kg} \mathrm{ha}^{-1} \mathrm{~N}$, respectively.

The dimensions of each elementary plot were $1.60 \times 1.20 \mathrm{~m}$. The seedlings were planted manually in January for both experiments and crops, 8 rows of wheat and 6 rows of faba bean (inter-rows $20 \mathrm{~cm}$ ) for full density $\mathrm{SC}$, whereas 4 rows of wheat and 3 rows of faba bean for IC (inter-rows $20 \mathrm{~cm}$ ) and SC/2 (inter-rows $40 \mathrm{~cm}$ ). The harvesting of the whole plots was done manually in July for wheat and in May for faba bean for both experiments. The seeding density was 320 plants per $\mathrm{m}^{2}$ for soft wheat 
as a SC, 40 plants per $\mathrm{m}^{2}$ for faba bean as a $\mathrm{SC}$, and 160 per $\mathrm{m}^{2}$ plants for soft wheat as $\mathrm{SC} / 2$ and 20 plants per $\mathrm{m}^{2}$ for faba bean as SC/2 and IC. At the seed maturity stage, the grain yield was evaluated by counting the number of wheat spikes and bean pods per $\mathrm{m}^{2}$, number of grains per spike or pod and thousand grain weight. For statistical analysis, these measurements were recorded on a plot basis and were converted to hectare. The root and shoot dry weight (DW) was determined in April after drying at $70^{\circ} \mathrm{C}$ temperature for $48 \mathrm{~h}$.

Competitive relationship and yield advantage. Land equivalent ratio ( $L E R$ ) is defined as the relative area of sole crops (SC) necessary to produce the yield or the biomass of intercrops (IC) (Bedoussac, Justes, 2011) and is calculated as follows:

$$
\begin{aligned}
& L E R \\
& \left.Y_{\text {faba SC SCat }}\right), \operatorname{LER}=\left(\mathrm{L}_{\text {wheat }}+\mathrm{L}_{\text {faba. }}\right. \text {. }
\end{aligned}
$$

LER values $>1$ indicate an advantage from IC in terms of the use of environmental resources for plant growth: when LER $<1$, resources are used more efficiently by SC than by IC, when LER $=1$, indicate that grain yield in intercropping equals the grain yield in SC. Interspecific interaction (IE) yield index evaluates the effect of a cultivar composing intercrops (IC) on the second cultivar of IC by comparing the yield obtained by this second component in IC and in half-density sole crops (SC/2) (Bedoussac, Justes, 2011) as follows:

$$
\mathrm{IE}=\mathrm{Y}_{\text {wheat IC }} / \mathrm{Y}_{\text {wheat SC/2 }} \text {, }
$$

when IE $=1$, there is no interspecific competition, i.e., the intercrop faba bean row did not affect the intercrop wheat yield; when IE $<1$, the intercrop wheat yield is reduced by interspecific competition. On the other hand, when IE $>1$, the intercrop wheat yield is significantly higher than that of wheat sole crop due to the presence of an intercrop faba bean - this is called facilitation.

Intraspecific interaction (IA) yield index evaluates the effect of a cultivar on itself in sole crop (SC) stand at full density by comparing the yield obtained in $\mathrm{SC}$ with double that in SC/2 (Bedoussac, Justes, 2011) as follows:

$$
\mathrm{IA}=\mathrm{Y}_{\text {wheat SC }} / 2 \times \mathrm{Y}_{\text {wheat SC/2}} \text {, }
$$

when IA $=1$, intraspecific competition is nil which means that adding a row of wheat to a SC with double-spaced rows did not affect the yield of the wheat rows; when IA $<1$, the yield of single-spaced wheat rows is reduced by IA competition. On the other hand, when IA $>1$, the yield of single-spaced wheat rows is increased by IA interaction (facilitation).

Biochemical and mineral analyses. The plants of both crops were sampled randomly at the full flowering stage of the faba bean and heading stage of wheat in the $1^{\text {st }}$ and $2^{\text {nd }}$ experiments (April) as a rate of three replicates per treatment. As for the biochemical analysis, $50 \mathrm{mg}$ of the fresh plants of each sample were used. The soluble leaf proteins were determined by an assay with Coomassie blue according to the Bradford (1976) method, total sugars were determined by ethanol method (Dubois et al., 1956), total leaf chlorophyll content was determined by acetone method (Arnon, 1949), and nitrate reductase activity (NRA) was measured as described by Heuer and Plaut (1978). For nutrient content, the plants were dried, crushed and mineralized. The content of macronutrients potassium $(\mathrm{K})$ and calcium $(\mathrm{Ca})$ was determined by atomic absorption spectrophotometry (Gaines, Mitchell, 1979), phosphorus (P) content was determined by colorimetry (Olsen, Watanabe, 1957).

Statistical analysis. The data were processed using a two-factor analysis of variance (ANOVA) with the statistical software package SPSS, version 20.0 (IBM Inc.) for each year, considering $\mathrm{N}$ treatments as the main factor, crops as a sub-factor and interaction between $\mathrm{N}$ treatments and crops. The differences between treatments were determined using Tukey's honestly significant difference (HSD) test. Means with different letters are significantly different at $p<0.05$. Six plants per treatment were used as repetition and grouped as three replicates. In order to compare the means of LER, IE and IA with 1 and partial LER values with 0.5 , LER values and partial LER values, IE and IA values were calculated from replicates assuming normal distribution according to Sheskin (2004).

\section{Results}

Competitive relationships and yield advantages.

In the $1^{\text {st }}$ experiment, as compared with sole crops (SC) intercrops (IC) increased wheat grain yield of but not significantly (Table 2 ). However, in the $2^{\text {nd }}$ experiment, the intercrops decreased wheat grain yield of at all $\mathrm{N}$ treatments compared to SC. The highest decrease was at $0 \mathrm{~kg} \mathrm{ha}-1 \mathrm{~N}$, when reductions were $30.4 \%$ for $\mathrm{SC}$ and $8.2 \%$ for $\mathrm{SC} / 2$ in the $2^{\text {nd }}$ experiment. Moreover, IC significantly decreased faba bean grain yield in all $\mathrm{N}$ treatments as compared to SC in both experiments; also, it showed at 50 and $100 \mathrm{~kg} \mathrm{ha}^{-1} \mathrm{~N}$ a sionificant decrease compared to $0 \mathrm{~kg} \mathrm{ha}^{-1} \mathrm{~N}$. While $\mathrm{N}$ significantly increased wheat grain yield, the highest increases were obtained at $100 \mathrm{~kg} \mathrm{ha}^{-1} \mathrm{~N}: 115.4,104.6$ and $127.6 \%$ for SC, SC/2 and IC, respectively, compared to the $0 \mathrm{~kg} \mathrm{ha}^{-1} \mathrm{~N}$ in the $2^{\text {nd }}$ experiment. In the $1^{\text {st }}$ experiment, no significant difference was found between $\mathrm{N}$ treatments in wheat grain yield for SC, SC/ 2 and IC, while in the $2^{\text {nd }}$ experiment, wheat grain yield was higher at $100 \mathrm{~kg} \mathrm{ha}^{-1} \mathrm{~N}$ compared to 50 and 0 $\mathrm{kg} \mathrm{ha}^{-1} \mathrm{~N}$ for SC, SC/2 and IC. For both experiments, grain yield of intercropped faba bean was significantly reduced with $\mathrm{N}$ fertilisation compared to $\mathrm{SC}$.

The insertion of wheat in IC the shoot biomass of faba bean significantly reduced by $36.38 \%\left(1^{\text {st }}\right.$ experiment) and $65.64 \%$ ( $2^{\text {nd }}$ experiment) compared to $\mathrm{SC}$ in the absence of $\mathrm{N}$ fertiliser (Table 3). During the $2^{\text {nd }}$ experiment, the root biomass of faba bean decreased significantly; otherwise, there was no significant change in the $1^{\text {st }}$ experiment. In parallel, without $N$ fertiliser the intercropped wheat shoot biomass showed a significant increase in the order of $59 \%, 22.7 \%$ compared to SC and $28.9 \%, 54.7 \%$ compared to $\mathrm{SC} / 2$ in the $1^{\text {st }}$ and $2^{\text {nd }}$ experiments, respectively. On the other hand, intercropped wheat increased root biomass under $\mathrm{N}$ treatment compared to the $\mathrm{SC}$ in the $1^{\text {st }}$ experiment. However, in the $2^{\text {nd }}$ experiment, the root biomass did not show any significant change (except for $50 \mathrm{~kg} \mathrm{ha}^{-1} \mathrm{~N}$ in $\mathrm{IC})$ compared to SC and SC/2.

The overall land equivalent ratio (LER) values calculated from the yield were greater than 1 for both experimental years and for all $\mathrm{N}$ treatments. Indeed, LER values were above the diagonal line corresponding to $\mathrm{LER}=$ 1 (except for $50 \mathrm{~kg} \mathrm{ha}^{-1} \mathrm{~N}$ in the $2^{\text {nd }}$ experiment) indicating a better valorisation of the resources by intercrops compared to SC (Figure 2). The LER of the wheat and faba bean intercrop was significantly positively correlated with $\mathrm{N}$ fertilisation In the $1^{\text {st }}$ experiment, the LER values were 1.94, 1.88 and 2.17 for 0,50 and $100 \mathrm{~kg} \mathrm{ha}^{-1} \mathrm{~N}$, respectively, and in the $2^{\text {nd }}$ experiment $-1.19,1.20$ and 1.67 , for 0,50 and $100 \mathrm{~kg}$ $\mathrm{ha}^{-1} \mathrm{~N}$, respectively. In both experiments, partial LER values for wheat were significantly greater than $0.5(p<0.001)$; however, partial LER values for faba bean were less than 0.5 . Therefore, it can be concluded that the two experiments led to a situation, in which wheat reduced the legume production (LER faba bean $<0.5$ and LER wheat $>0.5$ ) corresponding to a better growth of wheat plants in IC than in SC, while the growth of legumes was reduced.

In the absence of $N$ fertiliser, the wheat IE value was close to 1 in the $2^{\text {nd }}$ experiment $(0.92)$ indicating that the presence of legume in IC did not affect wheat productivity compared to $\mathrm{SC} / 2$ and suggesting that faba bean competition was almost nil. When the $\mathrm{N}$ fertiliser was applied, in the $2^{\text {nd }}$ experiment, the IE value was increased to 0.94 and 1.02 for 50 and $100 \mathrm{~kg} \mathrm{ha}^{-1} \mathrm{~N}$, respectively. Similarly, in the $1^{\text {st }}$ experiment, the presence of the legume was associated with a greater facilitation effect on wheat $\mathrm{IC}$, inducing an increase in yield compared to $\mathrm{SC} / 2$ as indicated by the high IE values: 1.47 at $0 \mathrm{~kg} \mathrm{ha}^{-1} \mathrm{~N}, 1.65$ at $50 \mathrm{~kg} \mathrm{ha}^{-1} \mathrm{~N}$ and 1.57 at $100 \mathrm{~kg} \mathrm{ha}^{-1} \mathrm{~N}$ (Figure 3 ).

For both experiments, wheat IA values were less than 1: 0.49 for the $1^{\text {st }}$ experiment and 0.66 for the $2^{\text {nd }}$ experiment, revealing that the wheat yield in $\mathrm{SC}$ was higher than that in SC/2 due to the lower density and the ability of the wheat to compensate for it by producing more tillers (11 tillers per shoot on average) (results not presented). Also, the wheat IE values was higher than the IA values for both experiments indicating that IA competition was stronger than IE one. This shows that in our experiment one row of wheat reduced wheat yield more than one row of faba bean. Indeed, in the absence of $\mathrm{N}$ fertiliser the IE and IA values were lower than those of 50 and $100 \mathrm{~kg} \mathrm{ha}^{-1} \mathrm{~N}$ for both experiments. This indicates that IE and IA competition were greatest without $\mathrm{N}$ fertiliser (Figure 3). 
Table 2. Grain yield of the sole crops (SC), half density sole crops (SC/2) and intercrops (IC) of wheat and faba bean under three nitrogen $(\mathrm{N})$ treatments

\begin{tabular}{|c|c|c|c|c|c|}
\hline \multirow{2}{*}{$\begin{array}{l}\text { Cropping } \\
\text { system }\end{array}$} & \multirow{2}{*}{$\begin{array}{c}\mathrm{N} \text { fertiliser } \\
\mathrm{kg} \mathrm{ha}^{-1}\end{array}$} & \multicolumn{2}{|c|}{$1^{\text {st }}$ experiment } & \multicolumn{2}{|c|}{$2^{\text {nd }}$ experiment } \\
\hline & & faha hean & grain yi & $\mathrm{ha}^{-1}$ & \\
\hline $\mathrm{SC}$ & $\begin{array}{c}0 \\
50 \\
100\end{array}$ & $6.43 \pm 1.17 \mathrm{ab}$ & $\begin{array}{l}3.29 \pm 0.08 \mathrm{cde} \\
5.17 \pm 2.26 \mathrm{abc}\end{array}$ & $4.05 \pm 0.16 \mathrm{~cd}$ & $4.01 \pm 0.52 \mathrm{~cd}$ \\
\hline $\mathrm{SC} / 2$ & $\begin{array}{c}0 \\
50 \\
100\end{array}$ & $5.71 \pm 1.52 \mathrm{abc}$ & $\begin{array}{l}3.37 \pm 0.68 \mathrm{cde} \\
3.31 \pm 0.98 \mathrm{cde} \\
4.19 \pm 0.47 \mathrm{bcd}\end{array}$ & $\begin{array}{c}1.4 \mathrm{f} \pm 0.11 \mathrm{~g} \\
-\end{array}$ & $\begin{array}{l}3.04 \pm 0.38 \mathrm{de} \\
3.72 \pm 0.76 \mathrm{c} \\
6.22 \pm 0.34 \mathrm{~b}\end{array}$ \\
\hline IC & $\begin{array}{c}0 \\
50 \\
100\end{array}$ & $\begin{array}{c}2.78 \pm 0.10 \mathrm{cde} \\
1.42 \pm 0.40 \mathrm{de} \\
1.10 \pm 0.32 \mathrm{e}\end{array}$ & $\begin{array}{l}4.97 \pm 0.39 \mathrm{abc} \\
5.45 \pm 0.67 \mathrm{abc} \\
6.57 \pm 0.63 \mathrm{ab}\end{array}$ & $\begin{array}{l}2.00 \pm 0.18 \mathrm{ef} \\
0.39 \pm 0.12 \mathrm{~g} \\
0.34 \pm 0.09 \mathrm{~g}\end{array}$ & $\begin{array}{l}2.79 \pm 0.23 \mathrm{e} \\
4.44 \pm 0.59 \mathrm{c} \\
6.35 \pm 0.32 \mathrm{~b}\end{array}$ \\
\hline
\end{tabular}

Note. Values are the mean of three replicates \pm standard errors; values in the same column followed by different letters are significant at $p<0.05$.

Table 3. Shoot and root dry weight of the sole crops (SC), half density sole crops (SC/2) and intercrops (IC) of wheat and faba bean under three nitrogen $(\mathrm{N})$ treatments

\begin{tabular}{|c|c|c|c|c|c|}
\hline \multicolumn{6}{|c|}{$1^{\text {st }}$ experiment } \\
\hline \multirow{2}{*}{$\begin{array}{l}\text { Cropping } \\
\text { system }\end{array}$} & \multirow{2}{*}{$\begin{array}{c}\mathrm{N} \text { fertiliser } \\
\mathrm{kg} \mathrm{h}^{-1}\end{array}$} & \multicolumn{2}{|c|}{ Shoot dry weight, $\mathrm{g}$ plant ${ }^{-1}$} & \multicolumn{2}{|c|}{${\text { Root dry weight, } \text { g plant }^{-1}}$} \\
\hline & & faba bean & wheat & faba bean & wheat \\
\hline $\mathrm{SC}$ & $\begin{array}{c}0 \\
50 \\
100 \\
\end{array}$ & $\begin{array}{c}127.1 \pm 9.04 \mathrm{cde} \\
- \\
-\end{array}$ & $\begin{array}{l}106.95 \pm 3.51 \mathrm{efg} \\
152.70 \pm 2.21 \mathrm{abc} \\
135.10 \pm 11.18 \mathrm{cde}\end{array}$ & $\begin{array}{c}13.51 \pm \\
\pm= \\
-\end{array}$ & $\begin{array}{l}12.66 \pm 1.30 \mathrm{cde} \\
12.62 \pm 0.06 \mathrm{cde} \\
14.34 \pm 0.04 \mathrm{bcd}\end{array}$ \\
\hline $\mathrm{SC} / 2$ & $\begin{array}{c}0 \\
50 \\
100\end{array}$ & $\begin{array}{c}139.05 \pm 6.20 \mathrm{bcd} \\
- \\
- \\
\end{array}$ & $\begin{array}{l}131.92 \pm 8.02 \mathrm{cde} \\
155.14 \pm 5.71 \mathrm{abc} \\
109.85 \pm 5.03 \mathrm{def}\end{array}$ & $\begin{array}{c}14.75 \pm 0.55 \mathrm{abc} \\
- \\
-\end{array}$ & $\begin{array}{c}13.07 \pm 0.41 \mathrm{bcde} \\
13.50 \pm 0.28 \mathrm{f} \\
11.74 \pm 0.38 \mathrm{def}\end{array}$ \\
\hline IC & $\begin{array}{c}0 \\
50 \\
100\end{array}$ & $\begin{array}{c}80.85 \pm 5.28 \mathrm{fgh} \\
69.43 \pm 1.87 \mathrm{~h} \\
76.92 \pm 6.48 \mathrm{gh}\end{array}$ & $\begin{array}{l}170.10 \pm 5.67 \mathrm{ab} \\
171.74 \pm 7.58 \mathrm{a} \\
176.27 \pm 6.46 \mathrm{a} \\
\end{array}$ & $\begin{array}{l}14.54 \pm 0.37 \mathrm{abc} \\
11.04 \pm 0.82 \mathrm{ef} \\
14.80 \pm 0.43 \mathrm{abc}\end{array}$ & $\begin{array}{l}14.63 \pm 0.65 \mathrm{bc} \\
15.77 \pm 0.24 \mathrm{~b} \\
17.26 \pm 0.93 \mathrm{a}\end{array}$ \\
\hline \multicolumn{6}{|c|}{$2^{\text {nd }}$ experiment } \\
\hline system & $\mathrm{kg} \mathrm{ha}^{-1}$ & faba bean & wheat & faba bean & wheat \\
\hline $\mathrm{SC}$ & $\begin{array}{c}0 \\
50 \\
100\end{array}$ & $\begin{aligned} 37.87 & \pm 1.82 \mathrm{~b} \\
- & -\end{aligned}$ & $\begin{array}{c}26.25 \pm 0.5 \mathrm{de} \\
28.58 \pm 1.40 \mathrm{~cd} \\
22.12 \pm 0.11 \mathrm{f}\end{array}$ & $\begin{array}{c}6.40 \pm 0.34 \mathrm{bc} \\
- \\
-\end{array}$ & $\begin{array}{l}7.00 \pm 0.29 \mathrm{~b} \\
6.96 \pm 0.29 \mathrm{~b} \\
3.56 \pm 0.02 \mathrm{~d}\end{array}$ \\
\hline $\mathrm{SC} / 2$ & $\begin{array}{c}0 \\
50 \\
100 \\
\end{array}$ & $\begin{aligned} 23.94 & \pm 1.68 \text { ef } \\
& - \\
& -\end{aligned}$ & $\begin{array}{r}20.82 \pm 0.74 \mathrm{f} \\
27.30 \pm 0.20 \mathrm{de} \\
41.57 \pm 1.75 \mathrm{~b}\end{array}$ & $\begin{array}{c}6.52 \pm 0.64 \mathrm{bc} \\
- \\
-\end{array}$ & $\begin{array}{l}6.37 \pm 0.92 \mathrm{bc} \\
7.36 \pm 0.75 \mathrm{~b} \\
10.52 \pm 0.80 \mathrm{a}\end{array}$ \\
\hline $\mathrm{IC}$ & $\begin{array}{c}0 \\
50 \\
100 \\
\end{array}$ & $\begin{array}{l}13.01 \pm 1.08 \mathrm{~g} \\
11.37 \pm 0.65 \mathrm{~g} \\
20.72 \pm 0.69 \mathrm{f}\end{array}$ & $\begin{array}{l}32.22 \pm 0.27 \mathrm{c} \\
53.82 \pm 0.41 \mathrm{a} \\
31.54 \pm 1.47 \mathrm{c}\end{array}$ & $\begin{array}{l}3.11 \pm 0.30 \mathrm{~d} \\
2.37 \pm 0.25 \mathrm{~d} \\
5.20 \pm 0.36 \mathrm{c}\end{array}$ & $\begin{array}{l}7.16 \pm 0.13 \mathrm{~b} \\
11.02 \pm 0.37 \mathrm{a} \\
7.37 \pm 0.42 \mathrm{~b}\end{array}$ \\
\hline
\end{tabular}

Note. Values are the mean of three replicates \pm standard errors; values in the same column followed by different letters are significant at $p<0.05$.

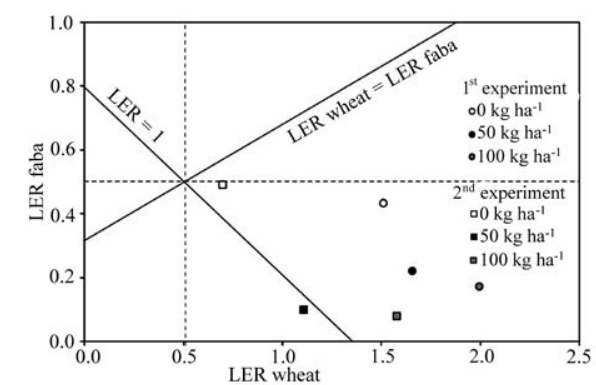

Note. Values represent the mean of three replicates.

Figure 2. Partial land equivalent ratio (LER) of faba bean as a function of the partial LER of wheat calculated from grain yield for three nitrogen $(\mathrm{N})$ treatments

Biochemical analysis. According to the results presented in Figure 4, the wheat IC without $\mathrm{N}$ fertiliser significantly increased the protein content by $75.1 \%$ and $76.7 \%$ compared to $\mathrm{N}, \mathrm{W}-\mathrm{SC} / 2$ in the $1^{\mathrm{st}}$ and $2^{\text {nd }}$ experiments, respectively. However, the addition of $\mathrm{N}$ on

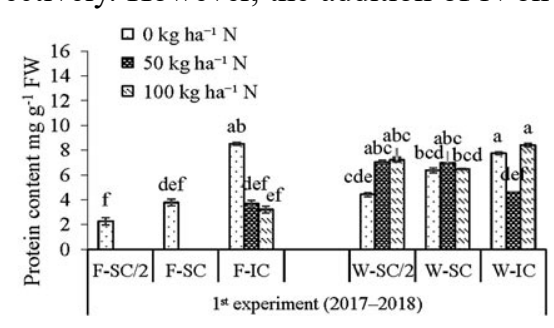

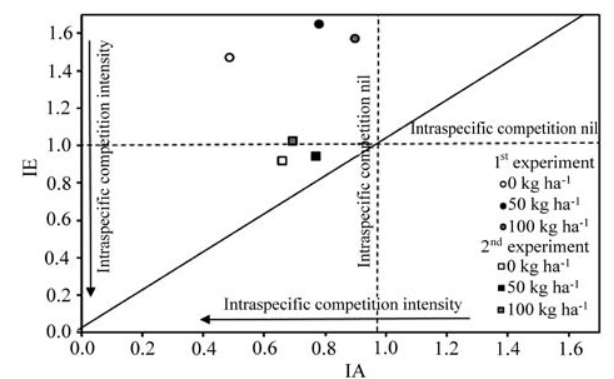

Note. Values represent the mean of three replicates.

Figure 3. Wheat interspecific interaction (IE) index as a function of wheat intraspecific interaction (IA) index calculated from grain yield for three nitrogen $(\mathrm{N})$ treatments

IC revealed no significant effect. Similarly, faba bean IC with no fertiliser very significantly $(p<0.001)$ increased the protein content compared to $\mathrm{SC}$. In fact, these increases were around $274.4 \%$ and $226 \%$ for the $1^{\text {st }}$ and $2^{\text {nd }}$ experiments, respectively, compared to F-SC/2. It was noted

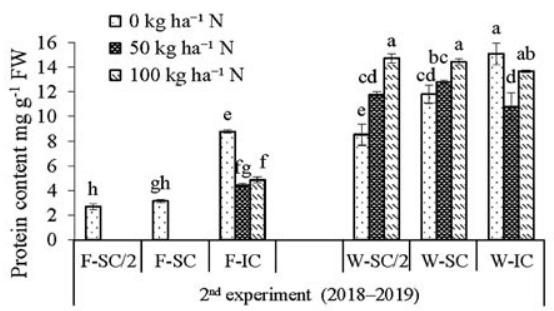

Note. Sole crops (SC) of faba bean (F): F-SC/2 - half density, F-SC - full density, F-IC - intercropped; wheat (W): W-SC/2 - half density, W-SC - full density, W-IC - intercropped; FW - fresh wight; values are the mean of three replicates; bars denote standard error; the different letters are significant at $p<0.05$.

Figure 4. Leaf protein content under three nitrogen $(\mathrm{N})$ treatments of wheat and faba bean as sole crops and intercrops 
that $\mathrm{N}$ fertiliser significantly increased the protein content in $\mathrm{SC}$ and SC/2 for both experiments. However, its application in IC reduced this element in both crops and experiments. It is interesting to note that the gain of protein obtained with organic $\mathrm{N}$ intake in sole crops was similar or less than that obtained in IC without $\mathrm{N}$ application.

In the absence of $\mathrm{N}$ fertiliser, the variations of nitrate reductase activity (NRA) of IC were all positive compared to SC (Figure 5). The IC induced the most significant increase in the activity of this enzyme. Indeed, these increases were in the order of $28.6 \%$ and $32.7 \%$ for wheat and $70.6 \%$ and $52.8 \%$ for faba bean compared to the $\mathrm{SC} / 2$ in the $1^{\text {st }}$ and $2^{\text {nd }}$ experiments, respectively. In contrast, the 50 and $100 \mathrm{~kg} \mathrm{ha}^{-1} \mathrm{~N}$ application slowed

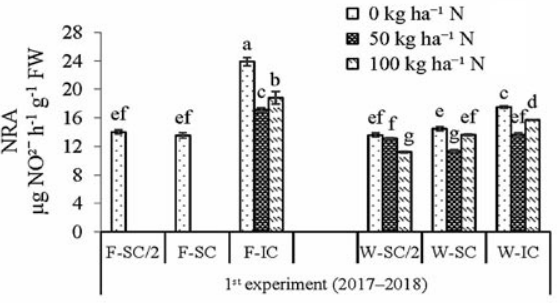

Explanations under Figure 4

Figure 5. Leaf nitrate reductase activity (NRA) under three nitrogen (N) treatments of wheat and faba bean as sole crops and intercrops
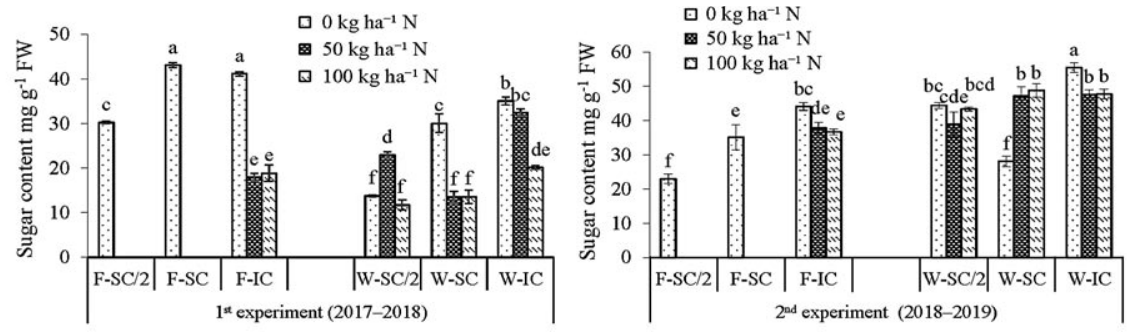

Explanations under Figure 4

Figure 6. Leaf sugar content under three nitrogen $(\mathrm{N})$ treatments of wheat and faba bean as sole crops and intercrops

An increase of the chlorophyll content in the leaves was recorded in wheat and faba bean IC in the absence of $\mathrm{N}$ fertiliser (Figure 7). The pronounced effect of chlorophyll content was recorded in the wheat IC with an increase of $39.1 \%$ and $156 \%$ compared to $0 \mathrm{~kg} \mathrm{ha}^{-1} \mathrm{~N}$ $\mathrm{W}-\mathrm{SC} / 2$ and $\mathrm{W}-\mathrm{SC}$, respectively, in the $1^{\text {st }}$ experiment, and with an increase of $14.7 \%$ and $25.8 \%$ compared to $0 \mathrm{~kg} \mathrm{ha}^{-1} \mathrm{~N} \mathrm{W-SC} / 2$ and W-SC, respectively, in the $2^{\text {nd }}$ experiment. Indeed, the chlorophyll content $0 \mathrm{~kg} \mathrm{ha}^{-1} \mathrm{~N}$ W-IC increased by $276 \%$ and $40 \%$ compared to $50 \mathrm{~kg} \mathrm{ha}^{-1}$

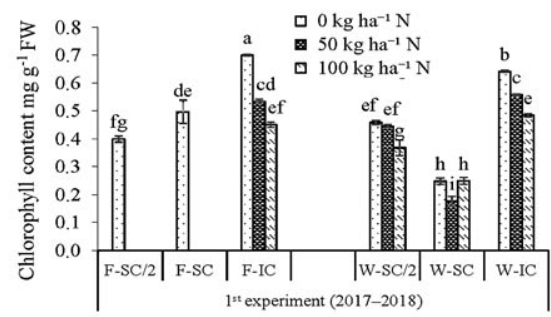

Explanations under Figure 4

Figure 7. Leaf chlorophyll content under three nitrogen $(\mathrm{N})$ treatments of wheat and faba bean as sole crops (SC) and intercrops (IC)

Mineral analysis. In terms of shoot $\mathrm{P}$ content, in the $2^{\text {nd }}$ experiment, a significant increase $(85 \%$ and $77 \%$ compared to F-SC and F-SC/2, respectively) was observed in faba bean IC without $\mathrm{N}$ fertiliser (Figure 8). Conversely, in $1^{\text {st }}$ experiment, growing faba bean IC showed a significantly lower shoot $\mathrm{P}$ content compared to SC (Figure 8 ). During the $1^{\text {st }}$ and $2^{\text {nd }}$ experiments, intercropped wheat without $\mathrm{N}$ fertiliser showed an increase in $\mathrm{P}$ content compared to $\mathrm{SC}$ and $\mathrm{SC} / 2$, but not significant.

The status of mineral nutrient $\mathrm{K}$ of the plants was enhanced by IC with better improvement recorded in the absence of $\mathrm{N}$ fertiliser with $35 \%$ and $94 \%$ for wheat
$\mathrm{NW}-\mathrm{SC}$ in the $1^{\text {st }}$ and $2^{\text {nd }}$ experiments, respectively, and by $156 \%$ and $34.5 \%$ compared to $100 \mathrm{~kg} \mathrm{ha}^{-1} \mathrm{~N} \mathrm{W-SC}$ in the $1^{\text {st }}$ and $2^{\text {nd }}$ experiments, respectively. On the other hand, IC significantly increased the chlorophyll content for faba bean by $40 \%$ and $75 \%$ compared to the sole crops of F$\mathrm{SC} / 2$ and $\mathrm{F}-\mathrm{SC}$, respectively, in the $1^{\text {st }}$ experiment, and by $30 \%$ compared to $0 \mathrm{~kg} \mathrm{ha}^{-1} \mathrm{~N}$ F-SC in the $2^{\text {nd }}$ experiment. However, the $\mathrm{N}$ treatment significantly decreased the chlorophyll content in SC and IC of both crops.

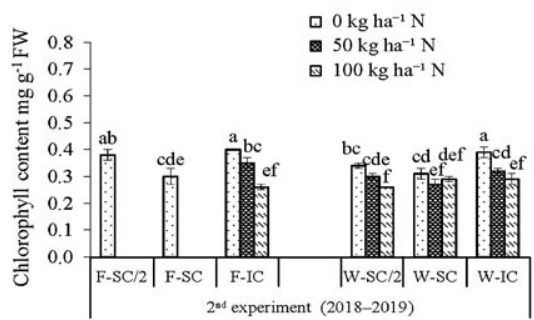

and $105 \%$ and $27.4 \%$ for faba bean compared to $\mathrm{SC} / 2$ in the $1^{\text {st }}$ and $2^{\text {nd }}$ experiments, respectively (Figure 9). Moreover, unfertilised wheat IC had a higher $\mathrm{K}$ content comparable to the SC fertilised for both experiments. In the $0 \mathrm{~kg} \mathrm{ha}^{-1} \mathrm{~N}$ treatment, faba bean IC induced a significant accumulation of $\mathrm{K}$. By contrast, the addition of $\mathrm{N}$ reduced the accumulation of this element.

In the absence of $\mathrm{N}$ fertiliser, $\mathrm{Ca}$ content was not showed any significant increase in most intercropped plants compared with the SC for both experiments. Indeed, the treatment also did not affect this element (Figure 10). the enzymatic activity and consequently resulted in the reduction in $\mathrm{N}$ fixation.

Figure 6 shows that sugar content increased significantly for both experiments in IC compared to SC. Without $\mathrm{N}$ fertiliser this increase was $155 \%$ and $24.7 \%$ for wheat IC and $36 \%$ and $91 \%$ for faba bean IC compared to $\mathrm{SC} / 2$ in the $1^{\text {st }}$ and $2^{\text {nd }}$ experiments, respectively. sugar content increased by $52.8 \%$ and $198 \%$ compared to $50 \mathrm{~kg} \mathrm{ha}^{-1} \mathrm{~N} \mathrm{~W}-\mathrm{SC} / 2$ and $100 \mathrm{~kg} \mathrm{ha}$ N W-SC/2 respectively; in the $2^{\text {nd }}$ experiment, an increase was $42 \%$ and $28 \%$ compared to $50 \mathrm{~kg} \mathrm{ha}^{-1} \mathrm{~N} \mathrm{W-SC} / 2$ and $100 \mathrm{~kg}$ $\mathrm{ha}^{-1} \mathrm{~N}$ W-SC/2, respectively. However, in the presence of $\mathrm{N}$ fertiliser, the IC did not show any interesting increases compared to the non-fertilised IC.

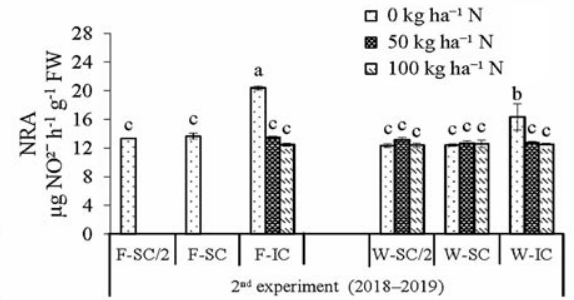


Explanations under Figure 4
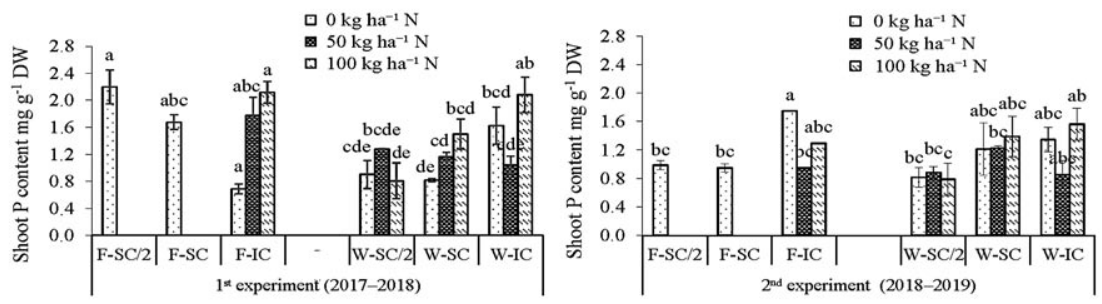

Figure 8. Phosphorus $(\mathrm{P})$ content in shoots under three nitrogen $(\mathrm{N})$ treatments in wheat and faba bean as sole crops and intercrops
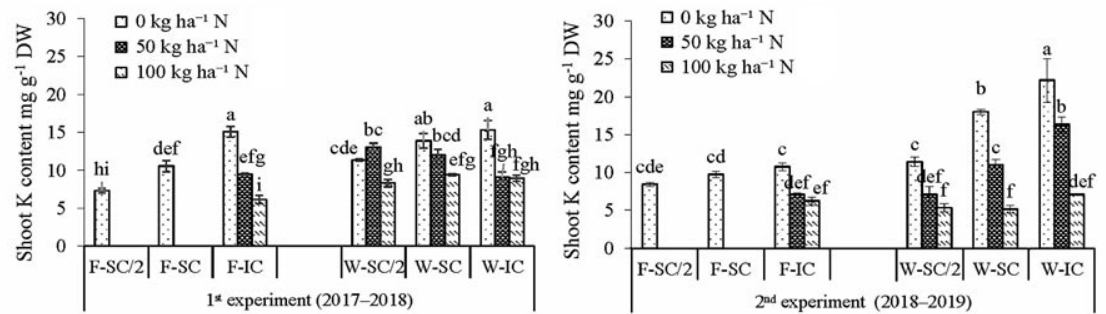

Explanations under Figure 4

Figure 9. Potassium $(\mathrm{K})$ content in shoots under three nitrogen $(\mathrm{N})$ treatments in wheat and faba bean as sole crops and intercrops

Explanations under Figure 4
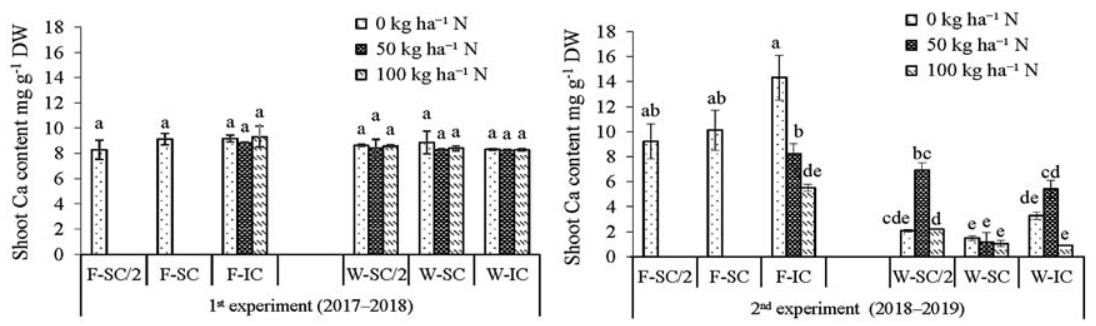

Figure 10. Calcium $(\mathrm{Ca})$ content in shoots under three nitrogen $(\mathrm{N})$ treatments in wheat and faba bean as sole crops and intercrops

\section{Discussion}

The research results showed that in the $2^{\text {nd }}$ experiment, the grain yield of faba bean intercropped with wheat decreased by $50.6 \%$ and $91.6 \%$ without $\mathrm{N}$ fertiliser and with $100 \mathrm{~kg} \mathrm{ha}^{-1} \mathrm{~N}$, respectively. Similar to results of Fan et al. (2006), the grain yield of faba bean intercropped with wheat decreased by $41 \%$ without $N$ application and by $23 \%$ at $120 \mathrm{~kg} \mathrm{ha}^{-1} \mathrm{~N}$, but not in a maize and faba bean intercrop. Moreover, the same study indicated that total biomass, grain yield and $N$ acquisition increased significantly when faba bean was intercropped with maize, but the values decreased when faba bean was intercropped with wheat, regardless of $\mathrm{N}$ fertiliser application. This indicate that the legume could gain or lose productivity in an intercrop situation depending on the companion crop. In the same study, the competitive ratio of faba bean relative to maize in intercropping was consistently higher than that in the wheat and faba bean intercrop, irrespective of $\mathrm{N}$ supply indicating a positive IE interaction between intercropped species in the maize-faba bean intercrop and a negative IE interaction in the wheat and faba bean intercrop. The intercropping yield may reduce many factors: species intercropped, competition for light, water and nutrients or allelopathic effects between mixed crops (Kermah et al., 2018).

By contrast, intercropped wheat had a positive and significant effect on total biomass and grain yield as evidenced by the higher LER over that found in sole cropping, which indicates better performance and resource use efficiency by intercropping. Several studies reported similar findings when growing maize and common bean (Nassary et al., 2019), rape and maize, rape and soybean, potato and maize, and soybean and potato intercropping (Dong et al., 2018). On the other hand, $\mathrm{N}$ fertilisation increased wheat LER. This is in accordance with the results obtained by Yu et al. (2015), who found that LER in intercropping increases with temporal complementarity between crop species and that this response to temporal complementarity is stronger at higher levels of $\mathrm{N}$ input.

As has been pointed out by Bedoussac and Justes (2011), IE and IA yield indices are more informative than partial LER ones, since IE and IA allow distinguishing the responses of a species to IE and IA interactions that occur simultaneously in intercrops and identification of possible facilitating situations. In our experiment, IA and IE were always less than 1 , except for IE in the $1^{\text {st }}$ experiment, where there was a facilitating effect of faba bean on intercropped wheat (IE > 1), indicating that wheat yield was reduced by IE and IA competition relative to half density. Also, it was observed that IA competition was stronger than IE one (IA $<$ IE). This shows that a row of wheat reduces wheat yield more than a row of faba bean.

In field and over two experiments, the wheat and faba bean IC had a significant positive effect on the leaf protein content. The same results were obtained by Bedoussac et al. (2012) by testing different combinations of intercropping: durum wheat and faba bean, durum wheat and peas, triticale and peas, and triticale and chickpea.

The research results showed that the IC tested improved protein content of cereals compared to the sole crops. This indicates that there is a positive relationship between wheat and legumes, modified by $\mathrm{N}$ fertilisation, density and cover structure, which will determine the performance of each species intercropped and thus improving or not the protein content of the cereal. Also, it may be explained by a high $\mathrm{N}$ fixation by legumes, which allows better $\mathrm{N}$ nutrition and better grain filling. Furthermore, the increased nitrate reductase activity (NRA) indicates that there was a $\mathrm{N}$ fixing activity in the IC wheat and faba bean, which was very important compared to monocropping, and when $\mathrm{N}$ fertiliser was added to the IC, this activity became slow. This high NRA in faba bean IC can be explained by the ability of legumes to fix atmospheric $\mathrm{N}$ and convert it into available $\mathrm{N}$, allowing wheat to benefit from it (Tang et al. 2018). Nevertheless, in the presence of $\mathrm{N}$ fertiliser, enzymatic activity was slowed down due to the high availability of $\mathrm{N}$ forms that can be assimilated by the plant. The research results showed that the amount of $\mathrm{N}$ fixed by the legume in cereal-legume intercropping depended on several factors such as species, plant morphology, crop density and available $\mathrm{N}$ in the soil. Pelzer et al. 
(2014) have explained the high atmospheric $\mathrm{N}$ fixation by the legume by the fact that the cereal rapidly depletes the mineral $\mathrm{N}$ available in the soil surface horizon.

The significant increase in chlorophyll content in the intercropped species compared to SC was an indication of a good operation of the light energy and water, better assimilation of $\mathrm{N}$ and other minerals and therefore, a better photosynthesis. Ahmad et al. (2013) also reported that garlic and pepper intercropping showed a significant positive effect on chlorophyll content.

Analysing $\mathrm{P}$ content, in the $1^{\text {st }}$ and $2^{\text {nd }}$ experiments, IC increased this element in wheat compared to SC however, this increase was not significant. Legumes could recover $\mathrm{P}$ from unavailable forms by secretion of organic acids that reduce the $\mathrm{pH}$ of the rhizosphere and release $\mathrm{P}$ from unavailable compounds. On the other hand, $\mathrm{P}$ facilitation between intercrop species might also be due to the differences in roots systems accessing different soil horizons and, hence, different forms of P (Stagnari et al. 2017). In addition, Latati et al. (2016) found that during two growing seasons plant $\mathrm{P}$ content increased in intercropped maize but decreased in intercropped common bean under P-deficient soil. In other studies (Ekhlas et al., 2012; Głowacka, 2014), an increased $\mathrm{K}$ uptake in intercropping has been observed in comparison to sole crops. Similarly, a study by Fan et al. (2020) showed an increase in $\mathrm{K}$ and $\mathrm{P}$ content in maize and soybean intercropping.

Also, intercropping affects other minerals such as $\mathrm{Ca}$. This is consistent with another study (Li et al., 2004) which found that wheat and chickpeas intercropping did not affect $\mathrm{Ca}$ content in wheat but increased $\mathrm{Ca}$ content in chickpeas, or by Glowacka (2014), who reported that IC increased the content of magnesium $(\mathrm{Mg})$ and $\mathrm{Ca}$ in maize. In fact, the accumulation of nutrients depends on the species mixed, the phenological stage, the dry matter production of shoots and the cultivation period (Partelli et al., 2011).

\section{Conclusions}

1. Under various nitrogen $(\mathrm{N})$ availabilities of field cereal-legume intercrops (IC) in Morocco, the analysis of certain indices: land equivalent ratio (LER), interspecific (IE) and intraspecific (IA) interaction, allowed to evaluate the efficiency of soft wheat IC with faba bean under various $\mathrm{N}$ applications. The total LER for grain yield of wheat and faba bean IC was greater than 1, which indicated that resources were used more efficiently for grain yield production compared to sole crops (SC) Moreover, wheat was more sensitive to IA interactions than to IE interactions $(\mathrm{IA}<\mathrm{IE})$. In the $1^{\text {st }}$ experiment, IE and IA competition was affected by $\mathrm{N}$ fertilisation.

These results indicated that the effect of a wheat row on another wheat row and the effect of a faba bean row on a wheat row (IA competition) depended strongly on $\mathrm{N}$ availability. However, in the $2^{\text {nd }}$ experiment, the IE and IA competition was not affected by $\mathrm{N}$ fertilisation, which indicated that the effect of a wheat row on another wheat row and the effect of a faba bean row on a wheat row were of a similar intensity whatever the $\mathrm{N}$ availability.

2 . In the $1^{\text {st }}$ experiment, the wheat grain yield IC was similar to that of SC and higher than that of hal density sole crops $(\mathrm{SC} / 2)$ treatments without or with $\mathrm{N}$ fertiliser $\left(0,50\right.$ and $\left.100 \mathrm{~kg} \mathrm{ha}^{-1} \mathrm{~N}\right)$. Nevertheless, in the $2^{\text {nd }}$ experiment, this parameter was similar to that of SC/2 and lower than that of SC in all $\mathrm{N}$ treatments. Wheat and faba bean IC without any $\mathrm{N}$ fertiliser had higher values of biochemical properties than SC without or with $\mathrm{N}$ inputs in both experiments. The mineral status ( $\mathrm{P}$ and $\mathrm{K}$ content) showed a significant increase in the abscence of $\mathrm{N}$ fertiliser IC compared to SC with or without $\mathrm{N}$ fertiliser, except for intercropped faba bean (F-IC) in the $1^{\text {st }}$ experiment. However, calcium $(\mathrm{Ca})$ content did not show any significant increase in both intercropped plants compared with the SC for both experiments.

Based on the results of this study, intercropping can be used as an alternative way to $\mathrm{N}$ application, but repetition over the years and in different environmental conditions is necessary to validate the findings.

\section{Acknowledgements}

Sincere thanks to the Regional Center for Agronomic Research of Marrakesh, Morocco (CRRA) for the availability of the experimental stations, their management and skilful experiences.

Received 04112020 Accepted 28042021

\section{References}

Arnon D. I. 1949. Copper enzymes in isolated chloroplasts. Polyphenolovidase in Reta vulgaric. Plant Physiology, 24 (1): 1-15. https://doi.org/10.1104/pp.24.1.1

Aubert G. $\overline{1} \hat{y} / \bar{\gamma}$. İiethodes d'anaiyses des sols (2ème ed.). Centre régional de Documentation Pédagogique, $191 \mathrm{p}$. (in French).

Ahmad I., Cheng Z., Meng H., Liu T., Nan W., Khan M. A., Wasila H., Khan A. R. 2013. Effect of intercropped garlic (Allium sativum) on chlorophyll contents, photosynthesis and antioxidant enzymes in pepper. Pakistan Journal of Botany, 45 (6): 1889-1896. http://www.pakbs.org/.../06.pdf

Baize D. 2018. Guides des Analyses Courantes en Pédologie (3e éd.). INRA, 328 p. (in French).

Bedoussac L., Justes E. 2011. A comparison of commonly used indices for evaluating species interactions and intercrop efficiency: application to durum wheat-winter pea intercrops. Field Crons Research 124 (1): 25-36 https://doi.org/10.1016/j.fcr.2011.05.025

Bedoussac L̀., Bernará L., Brauman A., Cohan J.-P. 2012. Les cultures associées céréale/légumineuse en agriculture "bas intrant" dans 1e Sud de 1a France. Projet $\Delta$ NIR PerfCom, $28 \mathrm{p}$ (in French). https://doi.org/10.13140/2.1.2888.0001

Betencourt E., Duputei ìi., Colomi $\bar{B}$., D̃esciaux $\bar{D}$., Hinsinger P. 2012. Intercropping promotes the ability of durum wheat and chickpea to increase rhizosphere phosphorus availability in a oux P soil. Soil Riology and Binchemictry 46: 181-90. https://doi.org/10.1016/j.soilbio.2011.11.015

Bradiford ivi ivi $i \hat{y} / 6$. A rapid and sensitive method for the quantitation microgram quantities of protein utilizing the principle of protein-dye binding. Analytical Biochemistry, 72 : 248-254. https://doi.org/10.1006/abio.1976.9999

Devau N., Hinsinger $\bar{Y}$., Le Cadre $\bar{E}$., Colomb B., Gerard F. 2011. Fertilization and $\mathrm{pH}$ effects on processes and mechanisms controlling dissolved inorganic phosphorus in soils Geochimica et Cosmochimica Acta 75 (10): 2980-2996. https://doi.org/10.1016/j.gca.2011.02.034

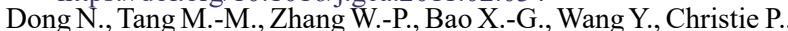
Li L. 2018. Temporal differentiation of crop growth as one of the drivers of intercronning vield advantage. Scientific Reports, 8: 3110. https://doi.org/10.1038/s41598-018-21414-w

Dubois M., Giiles $\widetilde{K}$. A., Hamiiton J. K., Kebers $\bar{P}$. A., Smith F. 1956. Colorimetric method for determination of sugars and related substances. Analytical Chemistry, 28 (3): 350-356. https://doi.org/10.1021/ac60111a017

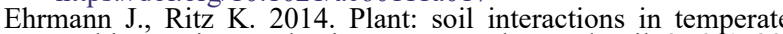
multi-cropning production svstems. Plant and Soil, 376: 1-29. https://doi.org/10.1007/s11104-013-1921-8

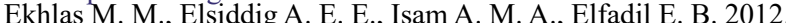
Intercropping sorghum (Sorghum bicolor L.) and cowpea (Vigna unguiculata L.): effect of bradyrhizobium inoculation and fertilization on minerals composition of sorghum seeds. International Scholarly Research Notices, 2012: 1-9. https://doi.org/10.5402/2012/356183

Fan $\overline{\mathrm{H}}$. Z Zhang $\overline{\mathrm{F}}$. Song $\bar{Y}$. Sun $\overline{\mathrm{J}}$., $\overline{\mathrm{B}}$ ao X., Guo T., Li L. 2006. Nitrogen fixation of faba bean (Vicia faba L.) interacting with a non-legume in two contrasting intercronning svstems. Plan and Soil, 283: 275-286. https://doi.org/10.1007/s11104-006-0019-y

Fan Y. Wang Z. Liao D. Kaza I. A. Wang B. Znang J Cnen J. Feng L., Wu X., Liu C., Yang W., Yang F. 2020. Uptake and utilization of nitrogen, phosphorus and potassium as related to yield advantage in maize-soybean intercropping under different row confimirations Scientific Reports, 10: 9504 https://doi.org/10.1038/s41598-020-66459-y

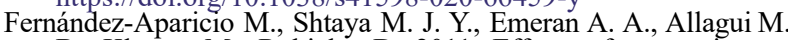
B., Kharrat M., Rubiales D. 2011. Effects of crop mixtures on chocolate spot development on faba bean grown in Mediterranean climates. Cron Protection, 39) (8): 1015-1023. https://doi.org/10.1016/j.cropro.2011.03.016

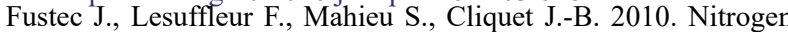
rhizodeposition of legumes. A review. Agronomy for Sustainable Develonment, 30 (1): 57-66 https://doi.org/10.1051/agro/2009003

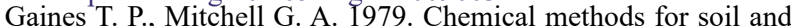
plant analysis. Agronomy Handbook, $105 \mathrm{p}$.

Gbakatchetche H., Sanogo S., Camara M., Bouet A., Keli J. Z. 2010. Effet du paillage par des residus de pois d'angole (Cajanus cajan L.) sur le rendement du riz (Oryza sativa) pluvial en zone forestiere de Côte d'Ivoire. A gronomie $\Delta$ fricaine, 22 (2): 131137 (in French). https://doi.org/10.4314/aga.v22i 2.68361

Głowacka A. 2014. The intiuence of strip cropping and adjacent plant species on the content and uptake of N, P, K, Mg and Ca by maize (Zea mays L.). Romanian Agricultural Research, 31: 219-227.

Gueguen L., Rombauts P. 1961. Dosage du sodium, du potassium, du calcium et du magnésium par spectrophotométrie de flamme dans les aliments, le lait et les excreta. Annales de Biologie animale, Riochimie, Rionhvsigue, 1 (1): 80-97 (in French). https://doi.org/10.1051/rnd/19611080

Heuer B., Plaut $\bar{Z}$. $\mid \bar{Y} \bar{\prime} \bar{\gamma}$. Keassessment of the in vivo asay for nitrate reductase in leaves. Physiologia Plantarum, 43 (3): 306-312. https://doi.org/10.1111/j.1399-3054.1978.tb02583.x

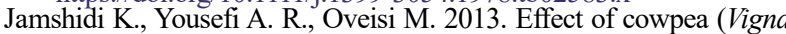
unguiculata) intercropping on weed biomass and maize (Zea mays) yield. New Zealand Inurnal of Cron and Horticultural Science, 41 (4): 180-188. https://doi.org/10.1080/01140671.2013.807853 
Kermah M., Franke A. C., Ahiabor B. D. K., Adjei-Nsiah S., Abaidoo R. C., Giller K. E. 2018. Legume-maize rotation or relay? Options for ecological intensification of smallholder farms in the Guinea savanna of northern Ghana. Experimental A griculture, 55 (5): 673-691. https://doi.org/10.1017/S0014479718000273

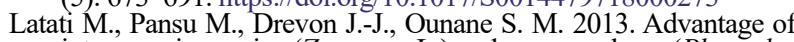
intercropping maize (Zea mays L.) and common bean (Phaseolus vulgaris L.) on yield and nitrogen uptake in Northeast Algeria. International Journal of Research in Applied Sciences, 01: 23-29.

Latati M., Bargaz A., Belarbi B., Lazali M., Benlahrech S., Tellah S., Kaci G., Drevon J. J., Ounane S. M. 2016. The intercropping common bean with maize improves the rhizobial efficiency, resource use and grain yield under low phosphorus availability. European Iournal of A gronomy, 72: 80-90. https://doi.org/10.1016/j.eja.2015.09.015

Li L., Iang C.., Kengei $\bar{Z}$., Zhang F. S. Zứ4. Calcium, magnesium and microelement uptake as affected by phosphorus sources and interspecific root interactions between wheat and chickpea. plant and Soil, 621: 20-37 https://doi.org/10.1023/B̈:PLSO.0000035579.39823.16

Li L., Zhang L. Z., Znang F. Z. Züij. Crop mixtures and the mechanisms of overyielding. Levin S. A. (ed.). Encyclopedia of Bindiversity (2nd ed. A scademic Press, USA vol. 2, p. 382-395.

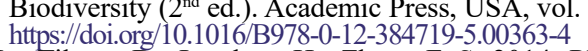

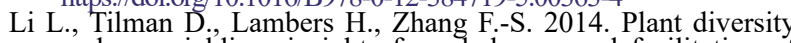
and overyielding: insights from belowground facilitation of intercronning in agriculture. New Phytologist, 203 (1): 63-69. https://doi.org/10.1111/nph. 12778

Lithourgidis A. S., Dordas C. A., Damaias C. A., Vlachostergios D. N. 2011. Annual intercrops: an alternative pathway for sustainable agriculture. Review article. Australian Inurnal of Crop Science, 5 (4): $396-410$. httrs://search.informit.org/dol $/ 10.3316$ / informit. 281409060336481

Nassary $\bar{E}$. K. . Baijukya F. i Ncakidemi P. A. 2019. Productivity of intercropping with maize and common bean over five cropping seasons on smallholder farms of Tanzania. European Journal of $\Delta$ gronomy 113: 125064 https://doi.org/10.1016/j.eja.2019.125964

Obaium S. E., Cunibuike G. U. U., Yeth S., Uuyang Y. 2017. Soil organic matter as sole indicator of soil degradation. Environmental Monitoring and $\Delta$ ccescment 180 (4): $32-50$ https://doi.org/10.1007/s10661-017-5881-y

Olsen S. K., Sommers L. E. i $\bar{y} \bar{\gamma} \bar{L}$. P̈hosphorus. Page A. L. (ed.) Methods of Soil Analysis. Part 2. American Society of Agronomy, Soil Science Society of America, p. 403-430. https://doi.org/10.2134/agronmonogr9.2.2ed.c24

Olsen S. K., watanabe $\overline{\mathrm{F}}$. S. $\mathbf{i} \bar{y} \bar{\jmath}$. A method to determine a phosphorus adsorption maximum of soils as measured by the Langmuir isotherm. Soil Science Society of America Journal, $21(2): 144-140$

https://doi.org/10.2136/sssaj1957.03615995002100020004x
Partelli F. L., Vieira H. D., Ferreira E. P. B., Viana A. P., Espindola J. A. A., Urquiaga S., Boddey R. M. 2011. Biologic dinitrogen

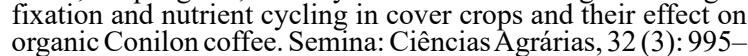

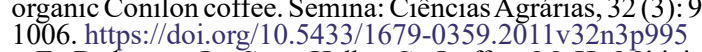

Pelzer E., Bedoussac L. Naudin C. 2014. Annual cereal-legume intercrops: feedback from farmers and analysis. Innovations Agronomiques, 40: $73-$ 91 (in French). https://hal.archives-ouvertes.fr/hal-01173338

Rusinamhodzi L., Corbeels M., Nyamangara J., Giller K. E. 2012. Maize-grain legume intercropping is an attractive option for ecological intensification that reduces climatic risk for smallholder farmers in central Mozambinue. Field Crons Research, 136: 12-22. https://doi.org/10.1016/j.fcr.2012.07.014

Shen J. B., Li C., Mi G., Li L., Yuan L. X., Jiang K., Zhang $\overline{\mathrm{F}}$. 2013. Maximizing root/rhizosphere efficiency to improve crop productivity and nutrient use efficiency in intensive agriculture of China. Review naner Inurnal of Fxnerimental Botany, 64 (5): 1181-1192. https://doi.org/10.1093/jxb/ers342

Sheskin D. J. 2004. Handbook of parametric and nonparametric statistical procedures ( $3^{\text {rd }}$ ed.). https://doi.org/10.1002/sim. 1895

Shili-Touzi I., De Tourdonnet S., Launay M., Dore 1. zUIU. Does intercropping winter wheat (Triticum aestivum) with red fescue (Festuca rubra) as a cover crop improve agronomic and environmental performance? A modeling approach. Field Crons Research 116 (3). 218-270

https://doi.org/10.1016/j.fer.2009.11.007

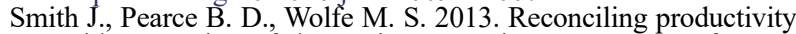
with protection of the environment: is temperate agroforestry the answer? Renewahle Aoriculture and Fond Svstems, 28 (1): 80-92. https://doi.org/10.1017/S1742170511000585

Stagnari F., Maggio A., Galieni A., Pisante M. 2017. Multiple benefits of legumes for agriculture sustainability: an overview. Chemical and Biological Technologies in Acriculture, 4 (2): 1-13. https://doi.org/10.1186/s40538-016-0085-1

Tang Q., Haile T., Liu H., Ken T., Jiang Ÿ., Zhai L̄., Lei B., Lin T., Liu E. 2018. Nitrogen uptake and transfer in broad bean and garlic strip intercropping systems. Journal of Integrative https://doi.org/10.1016/S2095-3119(17)61772-6

WRB́ Zui4. Worid reterence base for soil resources. World Soil B. LU14. World reterence base tor soil resources
Resnurces Renorts No. 106. FAO, n. 187-189. https://doi.org/10.1016/j.catena.2018.11.006

Yu Y., Stomph 1.-J., Makowski D., Wert van der W. 2015. Temporal niche differentiation increases the land equivalent ratio of annual intercrons: a meta-analysis. Field Crons Research, 184: annual intercrons: a meta-analysis. Field crons Re Red

Zhang X., Davidison E. A., Mauzeraii D. L.., Searchinger I. D., Dumas P., Shen Y. 2015. Managing nitrogen for suctainahle development. Nature, 528: 51-59. hittps://doi.org/10.1038/nature15743

\title{
Kviečių ir pupų mišinio įtaka augalų konkurencinei sąveikai, grūdų derlingumui, biocheminiams rodikliams ir mineralų kiekiui lapuose
}

\author{
H. Sammama ${ }^{1,2}$ M. El Kaoua ${ }^{2}$, D. Hsissou ${ }^{2}$, S. Latique ${ }^{3}$, K. Selmaoui ${ }^{3}$, M. N. Alfeddy ${ }^{1}$ \\ ${ }^{1}$ Marakešo regioninio agronominių tyrimų centro Augalų apsaugos skyrius, Marokas \\ ${ }^{2}$ Cadi Ayyad universiteto Gamtos mokslu ir technologijų fakultetas, Marokas \\ ${ }^{3}$ Ibn Tofail universiteto Gamtos mokslų fakultetas, Marokas
}

\section{Santrauka}

Ivairių tyrimụ rezultatai pabrèžia mišinių pasèliụ privalumus, pavyzdžiui, augalų augimo gerinimą, derliaus stabilizavimą ir ekonominès bei aplinkosauginès rizikos, būdingos vienanarių pasėlių sistemoms, mažinimą.

Siekiant palyginti veislès 'Wafia' žieminių kviečių ir veislès 'Alfia' paprastujų pupu auginimą vienanariame pasèlyje arba mišinyje, eksperimentas vykdytas du vegetacijos sezonus tręšiant skirtingais kiekiais azoto trąšų. Tyrimo tikslas - ịvertinti mišinių pasėlių efektyvumą pagal šiuos rodiklius: žemės ekvivalento santykị (LER) ir tarprūšinès (IE) bei vidurūšinès (IA) sąveikos indeksus, ir patikrinti, ar kviečių ir pupų mišinys pagerina abiejų veislių augalų grūdų derlingumą, biochemines savybes ir makroelementu pasisavinimą sistemose su mažomis azoto $(\mathrm{N})$ sąnaudomis. Tyrimo rezultatai parodè, kad mišinių pasėliai gamtinius išteklius efektyviausiai naudojo netręšiant azoto trąšomis $($ LER > 1). Minkštuosius kviečius auginant be trąšų, 2-ajame eksperimente IE buvo lygus 1; tai rodo, kad pupiniu augalų buvimas mišinyje neturejo įtakos kviečių produktyvumui, palyginti su vienanariame pusiau tankiame pasėlyje augintais augalais. Tačiau 1-ajame eksperimente pupiniai augalai didesnę ịtaką turèjo kviečių mišiniui (IE > 1) ir padidino jo derlingumą, palyginti su pusiau tankiu pasėliu. Abiejuose eksperimentuose kviečių IA buvo mažesnis nei 1; tai rodo, kad esant pilnam tankumui kviečių derlingumas pusiau tankiame pasėlyje buvo didesnis nei vienanariame. Abiejuose eksperimentuose azoto trąšomis netręštas kviečiu ir pupu mišinys padidino abieju rūšiu augalu baltymu, cukraus bei chlorofilo kiekị ir nitratų reduktazès aktyvumą, palyginti su netręštais ir tręštais vienanariais pasèliais. Makroelementų P ir K pasisavinimas padidejo mišinio pupose 1-ajame ir 2-ajame eksperimentuose, kai šių elementu dirvožemyje buvo mažiau, tačiau kalcio $(\mathrm{Ca})$ kiekiui reikšmingos įtakos nenustatyta. Tai leidžia daryti išvadą, kad minkštujų kviečių ir pupų mišinys yra tinkamas būdas mažinti cheminių trąšų naudojimą.

Reikšminiai žodžiai: mišinys, tarprūšinė ir vidurūšinė sąveika, tręšimas azotu, Triticum aestivum, Vicia faba, žemès ekvivalento santykis. 